\title{
ANALYSIS AND RESULTS: CONFIRMATORY FACTOR ANALYSIS THE MALAY VERSION OF DREEM INVENTORY WITH MEDICAL STUDENTS OF UNISZA, KUALA TERENGGANU, MALAYSIA
}

\section{MAINUL HAQUE ${ }^{1 *}$, MUHAMAD SAIFUL BAHRI YUSOFF² ${ }^{2}$ MD. ANWARUL AZIM MAJUMDER ${ }^{3}$, ZAINAL ZULKIFLI ${ }^{4}$, FARAH HANANI BINTI MOHD NASIR ${ }^{4}$}

\begin{abstract}
${ }^{1 *}$ Faculty of Medicine and Defence Health, Universiti Pertahanan Nasional Malaysia (National Defence University of Malaysia), Kem Sungai Besi, 57000 Kuala Lumpur, Malaysia. ${ }^{2}$ School of Medical Sciences, Universiti Sains Malaysia, 16150 Kubang Kerian, Kota Bharu, Kelantan, Malaysia. ${ }^{3}$ Faculty of Medical Sciences, The University of the West Indies, Cave Hill Campus, Barbados, West Indies. ${ }^{4}$ Faculty of Medicine, Medical Campus, Universiti Sultan Zainal Abidin, Jalan Sultan Mahmud, 20400 Kuala Terengganu, Terengganu, Malaysia. Email: runurono@gmail.com
\end{abstract}

Received: 10 August 2017, Revised and Accepted: 15 September 2017

ABSTRACT

Objectives: The DREEM inventory has been universally established as a generic instrument to assess health-related educational programs. There were some apprehensions regarding the psychometric properties of the DREEM raised in last few years. This study evaluated first ever the psychometric properties of the Bahasa Melayu version of the DREEM in a sample of Malaysian medical students.

Methods: A cross-sectional study was carried and universal sampling method was applied. Researchers selected 1-5 $5^{\text {th }}$-year medical students of Universiti Sultan Zainal Abidin, Malaysia, as study subjects. Researchers collected data through a guided self-administered questionnaire during a face-to-face session

Results: Confirmatory factor analysis (CFA) showed that the one factor model of DREEM-M (Model A), consisting 50 items were not fit, indicating it was a multidimensional instrument. On further CFA, it appeared that the proposed five-factor structure was not fit (Model B) as all the goodness-of-fit indices did not signify a model fit.

Conclusions: The study findings revealed that the DREEM inventory 50-item inventory failed to achieve a model fit, but it demonstrated a high of internal consistency. The proposed 19-item DREEM-M revealed good model fit.

Keywords: Confirmatory factor analysis, Malay version of DREEM, Malaysia.

(c) 2017 The Authors. Published by Innovare Academic Sciences Pvt Ltd. This is an open access article under the CC BY license (http://creativecommons. org/licenses/by/4. 0/) DOI: http://dx.doi.org/10.22159/ajpcr.2017.v10i12.21931

\section{INTRODUCTION}

The World Federation for Medical Education emphasized the teachinglearning environment as one of the principal objectives for the assessment of medical education programs, in 1998 [1]. It is widely established among medical educators and teachers that the effects of the educational environment, both academic and clinical, are important elements of medical students' attitudes, knowledge, skills, progression, and behaviors [2-5]. Dr. Sue Roff, a faculty member of the Centre for Medical Education of University of Dundee, Scotland, UK, was the principal scientist of a team and who developed the 50-item DREEM instrument utilizing a "Delphi panel of nearly 100 health professions educators from around the world and validation by over 1000 students in countries as diverse as Scotland, Argentina, Bangladesh and Ethiopia to measure and "diagnose" undergraduate educational climates in the health professions [6]." The DREEM is a 50-item inventory measure of students' perceptions of their learning environment resulting in scores on five scales. These are labeled, the perception of learning, the perception of course organizers, academic self-perception, the perception of atmosphere (SPoA), and social self-perception [6]. Medical educators and researchers of different parts of the world have tried to quantify the medical education environment and the most extensively utilizing the DREEM inventory [6,7-15]. Thereafter, the DREEM inventory has demonstrated itself globally valuable in a diverse health-care setting such as medical, dental, nursing, and chiropractic the teaching-learning environments [16-20]. The far majority these studies revealed that "variety of descriptive statistics for the scale items, subscales, and the total DREEM score; internal consistency (Cronbach's alpha); and correlational statistics, investigating relationships between the DREEM total and subscale scores with characteristics such as age, gender, and program year level" [21].

Structural equation modeling (SEM) is statistical procedures that one can use to decrease "the number of observed variables into a smaller number of latent variables by examining the covariation among the observed variables" [22]. SEM includes two components, i.e., confirmatory factor analysis (CFA) and structural model [23]. CFA is a confirmatory procedure-it is theory focused. Therefore, the preparation of the analysis is driven by the theoretical associations among the observed and unobserved variables. The researcher planned to measure a hypothesized model a population covariance matrix that is compared with the observed covariance matrix -CFA is conducted. Precisely, when any research intended to reduce the difference between the estimated and observed matrices [22]. Thereafter, CFA depicts the pattern of observed variables for those latent constructs hypothesized model [23]. CFA plays the role of validating and finding the reliability of any measurement in most social science studies [24]. Afterward, several study inventories have been CFA to measure the validity and reliability [25-30].

The Faculty of Medicine, UniSZA, is scheduled to conduct a major revision in the next few years of the undergraduate medical curriculum $[31,32]$. The Ministry of Higher Education of the Government of Malaysia to approved the University's medical program in Kuala Terengganu, Terengganu, Malaysia. The first group of 30 MBBS students, admitted in 2009, graduated in August 2014. Malaysian medical education is 
usually of a 5-year program and 2-year housemanship in hospitals owned by the Ministry of Health, Government of Malaysia [14,33-35].

This study aimed to evaluate the psychometric properties of Malay translated DREEM (DREEM-M) in a sample of Malaysian medical students. This study was designed to answer four questions: (i) Is DREEM-M a valid tool to measure the educational climate in a sample of Malaysia medical students? (ii) Is DREEM-M a reliable tool to measure the educational climate in a sample of Malaysia medical students? (iii) What is the best fit model of DREEM-M to measure the educational climate in the studied population? (iv) Does the internal consistency of DREEM-M vary across years of study? The authors hypothesized DREEM-M would demonstrate a high level of internal consistency; however, its construct validity will differ from the original construct proposed by the DREEM developers.

\section{METHODS}

A cross-sectional study was carried, and universal sampling method was applied. Based on the best practice of sample size calculation for a validation study, 5-10 samples per item were considered adequate to obtain a significant result [36], therefore a minimum number of study subject was 250 . Researchers selected $1-5^{\text {th }}$-year medical students in a public medical school (UniSZA) as study subjects. All medical students of UniSZA from 1-5th year of the MBBS program of session 2015-2016 were the target population. The total number of medical students at UniSZA was $300(60 \times 5=300)$. The universal sampling technique was used as the total sample size was small and obtains a significant result [36]. A pilot study was conducted among 10 undergraduate medical students $(2 \times 5=10,2$ students from each year) for Malay version of DREEM inventory and it was found that the survey instructions and items were easily comprehensible and suitable for the study. The students who participated in the pilot study were excluded from the final study. Researchers collected data through a guided selfadministered questionnaire during a face-to-face session. This study obtained ethical approval from UniSZA Research Ethics Committee, recorded as Memo Number UniSZA. C/1/UHREC/628-1 (44), Dated: 3 November 2015. Informed consent was obtained from the respondents before the questionnaire administration. Completion of DREEM-M was voluntary, and participants were informed that not returning it would not affect their progress in the medical study. DREEM-M was immediately returned after completion. Data were analyzed by Statistical Package for the Social Sciences version 22 (SPSS 22) and Analysis of Moment Structure software version 22 (AMOS 22).

The DREEM inventory was developed as a tool to measure educational climate at educational institutions [6,37] and was claimed as a "culturalfree" instrument [38]. There are 50 items measuring five aspects of the educational environment based on students' perception, which include students' perception of learning (SPoL), students' perception of teaching (SPoT), students' academic self-perception (SASP), students' perception of atmosphere (SPoA) and students' social self-perception (SSSP). Each item is rated based on five-Likert scales range between 0 and 4 ( 0 = strongly disagree, $1=$ disagree, 2 = unsure, $3=$ agree, and 4 = strongly agree). There are 9 negative items that must be scored in a reverse manner before analysis and interpretation; item 4, 8, 9, 17, $25,35,39,48$, and 50 [6]. It has been translated into various languages, and the reported overall Cronbach's alpha coefficient ranges from 0.89 to 0.93 [5,39-44]. The Malay translated DREEM was used in this study [45].

A descriptive analysis of the demographic data was performed by SPSS 22. CFA was performed to test measurement model of each latent construct. CFA was performed by AMOS 22. The latent constructs and the proposed model were considered fit if all the goodness-of-fit indices achieve minimal requirement (Table 1) [46]. Standardized factor loading (SFL), modification indices (MI), and standardized residual covariance's (SRC) were used as indicators for selecting items fit to be remain in the model [47]. The SFL signify contribution of items to their respective construct [47], MI suggest correlations between variables, therefore, reduction of Chi-square values signify its contribution to the model [47], and SRC estimate a standard normal distribution if the model is correct, thus if the model is correct, most of the items should have an SRC value of less than $\pm 2[47,48]$. Although the reduction in Chi-square values would improve model fit, following the suggestions in MI, SRC, and SFL should be based on a literature review or theoretical basis $[49,50]$. A correlation between constructs of $<0.85$ was considered as good discriminant validity thus supporting construct validity [47].

Table 1: Goodness-of-fit indices that were used to signify model fit

\begin{tabular}{lll}
\hline Name of category & Name of index & Level of acceptance \\
\hline Absolute fit $^{1}$ & RMSEA & $<0.08[51]$ \\
& GFI & More than 0.9 [52] \\
Incremental fit $^{2}$ & CFI & More than $0.9[53]$ \\
& TLI & More than $0.9[54]$ \\
& NFI & More than $0.9[55]$ \\
Parsimonious fit $^{3}$ & Chisq/df & $<5[56]$ \\
\hline
\end{tabular}

${ }^{1}$ Absolute fit: Measures overall goodness-of-fit for both the structural and measurement models collectively. This type of measure does not make any comparison to a specified null model (incremental fit measure) or adjust for the number of parameters in the estimated model (parsimonious fit measure). ${ }^{2}$ Incremental fit: Measures goodness-of-fit that compares the current model to a specified "null" (independence) model to determine the degree of improvement over the null model. ${ }^{3}$ Parsimonious fit: Measures goodness-of-fit representing the degree of model fit per estimated coefficient. This measure attempts to correct for any "overfitting" of the model and evaluates the parsimony of the model compared to the goodness-of-fit. RMSEA: Root mean square of error approximation, GFI: Goodness-of-fit index, CFI: Comparative fit index, TLI: Tucker-lewis index, NFI: Normed fit index, Chisq/df: Chi-square/degree of freedom

Reliability analysis was applied to determine the internal consistency of DREEM-M inventory. Internal consistency of items was evaluated by the Cronbach's alpha, corrected item-total correlation (CITC), and Cronbach's alpha if item deleted (CAID) values. The items were considered to represent an acceptable level of internal consistency if the Cronbach's alpha value within 0.5-0.7 and a good level if the Cronbach's alpha value more than $0.7[57,58]$. An item is considered to highly contribute to the measured construct if CITC value more than 0.3 and CAID value decreased [59].

\section{RESULTS}

A total of 277 medical students completely responded to the 50 statements of DREEM-M. Demographic profiles of participants were summarized in Table 2.

CFA showed that the one factor model of DREEM-M (Model A), consisting 50 items were not fit, indicating it was a multidimensional instrument (Table 3). On further CFA, it appeared that the proposed five-factor structure was not fit (Model B) as all the goodness-of-fit indices did not signify a model fit. Item reduction was performed based on MI, SRC, and SFL values to select which DREEM-M items should remain in the model [47]. As shown in Table 3, the five-factor model of DREEM-M with 19 items (Model G) was found to be model fit as all the goodness-of-fit indices signifies model fit.

SFL for the proposed five-factor structure of the 50-item DREEM-M (Model A) ranged between 0.05 and 0.79 , suggesting that certain items did not represent the construct being measured. Whereas, for the best fit model (i.e., Model G), the SFL ranged between 0.49 and 0.81 (Fig. 1), indicating that all items contributed highly to the constructs being measured. The majority of standardized correlation coefficients ( $\mathrm{r}$ ) between the five domains were more than 0.85 , except the correlation between SSSP-SASP ( $r=0.75$ ) and SSSP-SPoT ( $r=0.83$ ) (Fig. 1), suggesting that they might be assessing similar constructs [47].

Reliability analysis shows that the overall Cronbach's alpha values for the 50 item and 19-item DREEM-M were more than 0.9 , respectively 
(Table 4). Both versions showed a high level of internal consistency in measuring students' perception of educational climate. The Cronbach's alpha values for the five subscales of the 50-item DREEM-M ranged between 0.78 and 0.85 while for the 19-item DREEM-M ranged between 0.69 and 0.79 (Table 4). The subscales for both versions showed acceptable to a high level of internal consistency $[57,58]$ in measuring the five aspects of students' perception of educational climate. Reliability analysis showed that the internal consistency of DREEM-M for both versions varied across phases of study. The Cronbach's alpha values across phases of study for subscales of the 50-item DREEM-M ranged between 0.78 and 0.88 while for the 19-item DREEM ranged between 0.64 and 0.83 (Table 4). Reliability analysis shows that the original 50-items DREEM had CITC values ranged between 0.117 and 0.730 . This result reflected that certain items contribute poorly to the constructs being measured as the CITC values $<0.30$ [59]; item 17, 25, 48, and 50 (Table 5). In contrast, the CITC values for the 19-item DREEM ranged between 0.410 and 0.723 . It indicates that all the items in the

Table 2: Demographic profiles of participants

\begin{tabular}{ll}
\hline Variables & Frequency $(\%)(\mathbf{n}=\mathbf{2 7 7})$ \\
\hline Year of study & \\
$1^{\text {st }}$ year & $54(19.5)$ \\
$2^{\text {nd }}$ year & $56(20.2)$ \\
$3^{\text {rd }}$ year & $54(19.5)$ \\
$4^{\text {th }}$ year & $53(19.1)$ \\
$5^{\text {th }}$ year & $60(21.7)$ \\
Phase of study & \\
Preclinical & $110(39.7)$ \\
Clinical & $167(60.3)$ \\
Sex & $76(27.4)$ \\
Male & $201(72.6)$ \\
Female & \\
Race & $174(62.8)$ \\
Malay & $47(17.0)$ \\
Chinese & $53(19.1)$ \\
Indian & $3(1.1)$ \\
Other &
\end{tabular}

19-item DREEM highly contributed to the constructs being measured as the CITC values more than 0.3 (Table 6) [59].

\section{DISCUSSION}

The educational environment is exceedingly multifaceted and defining also a very difficult assignment. Educational environment has considered as "a set of factors that gives each situation a personality,

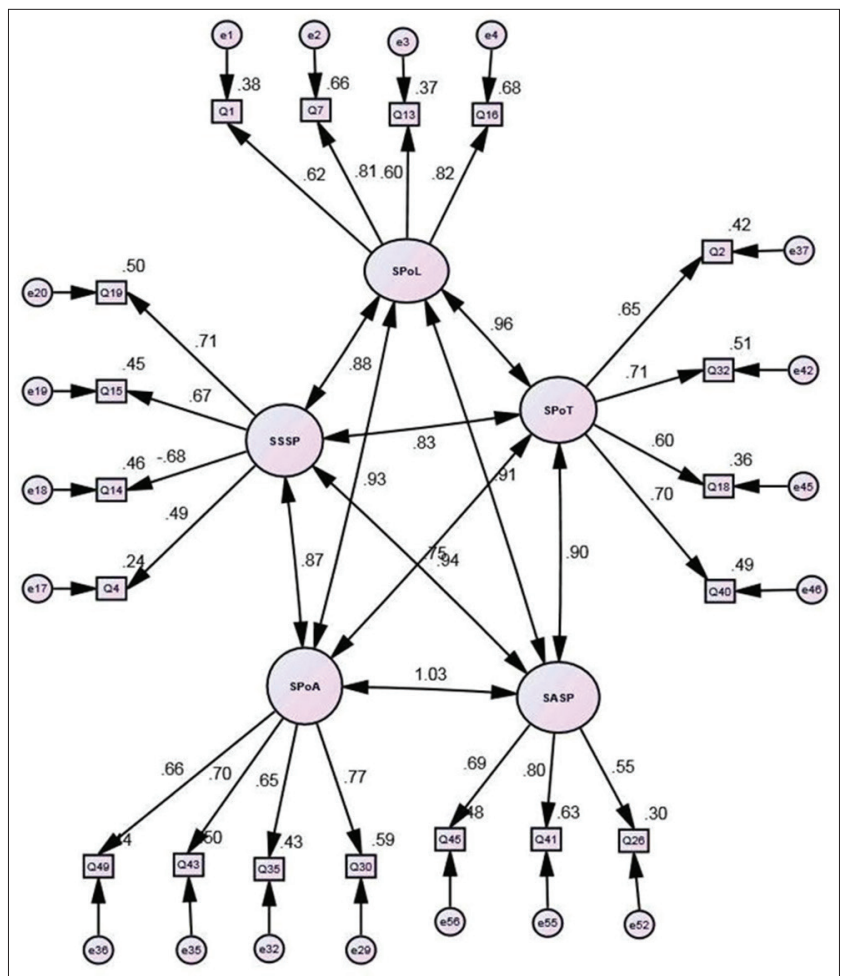

Fig. 1: Standardized factor loading for the best fit model of DREEM

Table 3: The results of CFA

\begin{tabular}{|c|c|c|c|c|c|c|c|c|}
\hline \multirow[t]{2}{*}{ DREEM model } & \multirow[t]{2}{*}{$X^{2}$ - statistic (df) } & \multirow[t]{2}{*}{ p-value } & \multicolumn{6}{|c|}{ Goodness-of-fit indices } \\
\hline & & & RMSEA & GFI & CFI & TLI & NFI & ChiSq/df \\
\hline Model A: One factor model (50 items) & 3140.93 (1175) & $<0.001$ & 0.078 & 0.644 & 0.736 & 0.725 & 0.638 & 2.673 \\
\hline Model B: Original five factors model (50 items) & $2998.14(1165)$ & $<0.001$ & 0.076 & 0.661 & 0.754 & 0.741 & 0.655 & 2.574 \\
\hline Model C: Yusoff (2012) model (17 items) & $305.11(109)$ & $<0.001$ & 0.081 & 0.882 & 0.914 & 0.893 & 0.874 & 2.799 \\
\hline Model D: Five factors model ( 40 items) & $1552.17(730)$ & $<0.001$ & 0.064 & 0.763 & 0.841 & 0.830 & 0.740 & 2.126 \\
\hline Model E: Five factors model ( 30 items) & $777.43(395)$ & $<0.001$ & 0.059 & 0.842 & 0.894 & 0.883 & 0.807 & 1.968 \\
\hline Model F: Five factors model (24 items) & $501.95(242)$ & $<0.001$ & 0.062 & 0.875 & 0.923 & 0.912 & 0.862 & 2.074 \\
\hline Model G: Five factors model (19 items) & $242.76(142)$ & $<0.001$ & 0.051 & 0.918 & 0.959 & 0.950 & 0.907 & 1.710 \\
\hline
\end{tabular}

Best fitting model in bold. Model D (item 9, 12, 22, 23, 27, 31, 38, 39, 42, and 44 were removed from Model B); Model E (item 6, 8, 10, 11, 20, 21, 24, 28, 36, and 47 were removed from Model D); Model F (item 5, 17, 25, 46, 48, and 50 were removed from Model E); Model G (item 3, 29, 33, 34, and 37 were removed from Model F)

Table 4: Cronbach's alpha values of the 50-item and 19-item DREEM-M

\begin{tabular}{|c|c|c|c|c|c|c|}
\hline \multirow[t]{3}{*}{ Domain } & \multicolumn{6}{|c|}{ Cronbach's alpha } \\
\hline & \multicolumn{3}{|c|}{ The 50-item DREEM-M } & \multicolumn{3}{|c|}{ The 19-item DREEM-M } \\
\hline & Preclinical & Clinical & Overall & Preclinical & Clinical & Overall \\
\hline DREEM-M & 0.951 & 0.937 & 0.943 & 0.894 & 0.859 & 0.874 \\
\hline SPL & 0.845 & 0.832 & 0.836 & 0.833 & 0.764 & 0.796 \\
\hline SPT & 0.826 & 0.831 & 0.826 & 0.791 & 0.725 & 0.754 \\
\hline SASP & 0.842 & 0.797 & 0.818 & 0.757 & 0.640 & 0.694 \\
\hline SSSP & 0.784 & 0.781 & 0.787 & 0.729 & 0.719 & 0.730 \\
\hline
\end{tabular}


Table 5: Reliability analysis of the 50 items of DREEM according to the five domains

\begin{tabular}{|c|c|c|c|}
\hline \multicolumn{2}{|c|}{ Number and statement } & CITC & CAID \\
\hline \multicolumn{4}{|c|}{ SPoL } \\
\hline 1 & I am encouraged to participate/Saya terdorong untuk mengambil bahagian & 0.553 & 0.819 \\
\hline 7 & The teaching is often stimulating/Setiap pengajaran selalu meransangkan & 0.730 & 0.805 \\
\hline 13 & The teaching is student-centered/Pengajaran menekankan pendekatan berpusat pada pelajar & 0.551 & 0.820 \\
\hline 16 & $\begin{array}{l}\text { The teaching is helpful to develop my skills /competency/Kaedah pengajaran membantu untuk meningkatkan } \\
\text { kemahiran/kecekapan saya }\end{array}$ & 0.728 & 0.807 \\
\hline 20 & The teaching is well focused/Kaedah pengajaran memberikan focus yang menyeluruh & 0.649 & 0.812 \\
\hline 24 & The teaching time is put to good use/Masa pengajaran digunakan dengan baik sekali & 0.682 & 0.810 \\
\hline 25 & The teaching over emphasizes factual learning*/Pengajaran terlalu menitikberatkan pembelajaran berasaskan fakta & -0.117 & 0.869 \\
\hline 38 & I am clear about the learning objectives of the course/Saya jelas tentang objektif pembelajaran dalam kursus ini & 0.614 & 0.816 \\
\hline 44 & $\begin{array}{l}\text { The teaching encourage me to be an active learner/Kaedah pengajaran memberikan semangat kepada saya untuk menjadi } \\
\text { pelajar yang aktif }\end{array}$ & 0.639 & 0.812 \\
\hline 47 & $\begin{array}{l}\text { Long-term learning is emphasized over short-term/Pembelajaran jangka panjang lebih ditekankan berbanding jangka } \\
\text { pendek }\end{array}$ & 0.535 & 0.821 \\
\hline 48 & The teaching is too teacher-centered*/Kaedah pengajaran terlalu menekankan pendekatan berpusat pada pengajar & -0.089 & 0.867 \\
\hline 2 & The teachers are knowledgeable/Pensyarah berpengetahuan luas & 0.687 & 0.792 \\
\hline 6 & $\begin{array}{l}\text { The teachers are emphasizes on patient-centered during their interaction with patients/Pensyarah menekankan } \\
\text { pendekatan berpusat kepada pesakit semasa berinteraksi bersama pesakit }\end{array}$ & 0.478 & 0.813 \\
\hline 8 & The teachers are ridicule the students*/Penyarah menyindir para pelajar & 0.563 & 0.805 \\
\hline 9 & The teachers are authoritarian*/Pensyarah terlalu memerintah & 0.674 & 0.795 \\
\hline 18 & $\begin{array}{l}\text { The teachers have good communication skills with the patients/Pensyarah mempunyai kemahiran komunikasi yang baik } \\
\text { dengan para pesakit }\end{array}$ & 0.481 & 0.813 \\
\hline 29 & $\begin{array}{l}\text { The teachers are good at providing feedback to students/Pensyarah bagus dalam menyediakan maklum balas kepada } \\
\text { pelajar }\end{array}$ & 0.675 & 0.794 \\
\hline 32 & The teachers provide constructive criticism here/Pensyarah memberikan kritikan yang membina di sini & 0.520 & 0.810 \\
\hline 37 & The teachers give clear examples/Pensyarah memberikan contoh-contoh yang jelas & 0.647 & 0.801 \\
\hline 39 & The teachers get angry is class*/Pensyarah adakala marah di dalam kelas & 0.272 & 0.832 \\
\hline 40 & The teachers are well prepared for their classes/Pensyarah bersedia dengan baik untuk kelas-kelas yang akan diajar & 0.637 & 0.800 \\
\hline 50 & The students irritate the teachers*/Para pelajar ada menyebabkan kemarahan kepada pensyarah & 0.002 & 0.859 \\
\hline \multicolumn{4}{|c|}{ SASP } \\
\hline 5 & $\begin{array}{l}\text { Learning strategies which work for me before continue to work for me now/Strategi pembelajaran yang digunapakai oleh } \\
\text { saya sebelum ini masih berkesan untuk saya sekarang }\end{array}$ & 0.494 & 0.805 \\
\hline 26 & $\begin{array}{l}\text { Last year work has been a good preparation for this year's work/Usaha pada tahun lepas telah menjadikan persediaan } \\
\text { yang baik kepada usaha tahun ini }\end{array}$ & 0.594 & 0.788 \\
\hline 27 & I am able to memorize all I need/Saya berkebolehan untuk mengingati semua yang perlu saya ingati & 0.539 & 0.797 \\
\hline 31 & I have learn a lot about empathy in my profession/Saya telah belajar banyak tentang rasa empati dalam kerjaya saya & 0.429 & 0.810 \\
\hline 41 & My problem skills are well developed here/Kemahiran penyelesaian masalah saya ditingkatkan dengan baik di sini & 0.586 & 0.792 \\
\hline 45 & $\begin{array}{l}\text { Much of what I have to learn seem relevant to career in health care/Kebanyakkan perkara yang saya perlu belajar dilihat } \\
\text { berkaitan dengan kerjaya saya dalam bidang kesihatan }\end{array}$ & 0.487 & 0.804 \\
\hline \multicolumn{4}{|c|}{ SPoA } \\
\hline 11 & The atmosphere was relax during ward teaching/Suasana sangat menenangkan semasa pengajaran di dalam wad & 0.405 & 0.857 \\
\hline 12 & The school is well timetabled/Universiti ini mempunyai jadual yang bagus & 0.563 & 0.846 \\
\hline 17 & Cheating is a problem in this school/Meniru adalah satu masalah di dalam universiti ini & 0.199 & 0.881 \\
\hline 23 & The atmosphere is relaxed during lectures/Suasana tenang semasa mendengar kuliah & 0.629 & 0.842 \\
\hline 30 & $\begin{array}{l}\text { There are opportunities for me to develop interpersonal skills/Di sini terdapat banyak peluang untuk saya meningkatkan } \\
\text { kemahiran interpersonal }\end{array}$ & 0.727 & 0.836 \\
\hline 33 & I feel comfortable in class socially/Saya berasa selesa di dalam kelas ketika bersosial & 0.674 & 0.842 \\
\hline 34 & The atmosphere is relaxed during seminars/tutorial/Suasana tenang semasa seminar/tutorial & 0.608 & 0.844 \\
\hline 35 & I found the experience disappointing/Saya merasakan pengalaman disini adalah mengecewakan & 0.616 & 0.843 \\
\hline 36 & I am able to concentrate well/Saya mampu menumpukan perhatian dengan baik & 0.593 & 0.846 \\
\hline 42 & The enjoyment outweighs the stress of studying medicine/Keseronokkan telah mengatasi tekanan belajar ilmu perubatan & 0.500 & 0.851 \\
\hline 43 & The atmosphere motivates me as a learner/Suasana memotivasikan saya sebagai pelajar & 0.629 & 0.842 \\
\hline 49 & I feel able to ask the questions I want/Saya boleh bertanya soalan yang saya mahu & 0.563 & 0.847 \\
\hline \multicolumn{4}{|c|}{ SSSP } \\
\hline 3 & $\begin{array}{l}\text { There is good support system for students who get stressed/Terdapat sistem sokongan yang baik untuk para pelajar yang } \\
\text { tertekan/stress }\end{array}$ & 0.479 & 0.763 \\
\hline 4 & I am too tired to enjoy this course/Saya terlalu letih untuk menikmati kursus ini & 0.416 & 0.774 \\
\hline 14 & I am rarely bored on this course/Saya jarang berasa bosan di dalam kursus ini & 0.588 & 0.744 \\
\hline 15 & I have good friends in this school/Saya mempunyai ramai kawan-kawan yang baik di dalam universiti ini & 0.505 & 0.758 \\
\hline 19 & My social life is good/Kehidupan sosial saya adalah baik & 0.661 & 0.727 \\
\hline 28 & I seldom feel lonely/Saya jarang berasa keseorangan & 0.503 & 0.759 \\
\hline 46 & My accommodation is pleasant/Tempat penginapan saya adalah selesa & 0.456 & 0.774 \\
\hline
\end{tabular}

*Negative item; CITC = Corrected Item-Total Correlation; CAID = Cronbach's Alpha if Item Deleted; Green Color is Malay Language. Notes: Items in italics are the negative statements. SPoL- Students' perceptions of learning; SPoT- Students' perceptions of teaching; SASP- Students' academic self-perceptions; SPoA- Students' perceptions of atmosphere; SSSP- Students' social self-perception. SPoL: Students' perception of learning, SPoT: Students' Perception of Teachers, SASP: Students' academic selfperception, SPoA: Students' perception of atmosphere, SSSP: Students' social self-perception 
Table 6: Reliability analysis on individual item of the best fit DREEM model

\begin{tabular}{|c|c|c|c|c|}
\hline Domain & No. & Statement & CITC & CAID \\
\hline \multirow[t]{4}{*}{ SPoL } & Q1 & I am encouraged to participate/Saya terdorong untuk mengambil bahagian & 0.518 & 0.795 \\
\hline & Q7 & The teaching is often stimulating/Setiap pengajaran selalu meransangkan & 0.723 & 0.687 \\
\hline & Q13 & The teaching is student-centered/Pengajaran menekankan pendekatan berpusat pada pelajar & 0.532 & 0.782 \\
\hline & Q16 & $\begin{array}{l}\text { The teaching is helpful to develop my skills /competency/Kaedah pengajaran membantu untuk } \\
\text { meningkatkan kemahiran/kecekapan saya }\end{array}$ & 0.680 & 0.714 \\
\hline \multirow[t]{4}{*}{ SPoT } & Q2 & The teachers are knowledgeable/Pensyarah berpengetahuan luas & 0.554 & 0.695 \\
\hline & Q18 & $\begin{array}{l}\text { The teachers have good communication skills with the patients/Pensyarah mempunyai kemahiran } \\
\text { komunikasi yang baik dengan para pesakit }\end{array}$ & 0.483 & 0.736 \\
\hline & Q32 & The teachers provide constructive criticism here/Pensyarah memberikan kritikan yang membina di sini & 0.585 & 0.679 \\
\hline & Q40 & $\begin{array}{l}\text { The teachers are well prepared for their classes/Pensyarah bersedia dengan baik untuk kelas-kelas yang } \\
\text { akan diajar }\end{array}$ & 0.593 & 0.677 \\
\hline \multirow[t]{3}{*}{ SASP } & Q26 & $\begin{array}{l}\text { Last year work has been a good preparation for this year's work/Usaha pada tahun lepas telah menjadikan } \\
\text { persediaan yang baik kepada usaha tahun ini }\end{array}$ & 0.410 & 0.743 \\
\hline & Q41 & $\begin{array}{l}\text { My problem skills are well developed here/Kemahiran penyelesaian masalah saya ditingkatkan dengan baik } \\
\text { di sini. }\end{array}$ & 0.600 & 0.494 \\
\hline & Q45 & $\begin{array}{l}\text { Much of what I have to learn seem relevant to career in health care/Kebanyakkan perkara yang saya perlu } \\
\text { belajar dilihat berkaitan dengan kerjaya saya dalam bidang kesihatan }\end{array}$ & 0.538 & 0.567 \\
\hline \multirow[t]{4}{*}{ SPoA } & Q30 & $\begin{array}{l}\text { There are opportunities for me to develop interpersonal skills/Di sini terdapat banyak peluang untuk saya } \\
\text { meningkatkan kemahiran interpersonal }\end{array}$ & 0.676 & 0.690 \\
\hline & Q35 & I found the experience disappointing/Saya merasakan pengalaman disini adalah mengecewakan & 0.558 & 0.754 \\
\hline & Q43 & The atmosphere motivates me as a learner/Suasana memotivasikan saya sebagai pelajar & 0.590 & 0.732 \\
\hline & Q49 & I feel able to ask the questions I want/Saya boleh bertanya soalan yang saya mahu & 0.553 & 0.751 \\
\hline \multirow[t]{4}{*}{ SSSP } & Q4 & I am too tired to enjoy this course/Saya terlalu letih untuk menikmati kursus ini & 0.434 & 0.721 \\
\hline & Q14 & I am rarely bored on this course/Saya jarang berasa bosan di dalam kursus ini & 0.528 & 0.666 \\
\hline & Q15 & I have good friends in this school/Saya mempunyai ramai kawan-kawan yang baik di dalam universiti ini & 0.566 & 0.642 \\
\hline & Q19 & My social life is good/Kehidupan sosial saya adalah baik & 0.562 & 0.647 \\
\hline
\end{tabular}

CITC: Corrected item-total correlation, CAID: Cronbach's alpha if item deleted, SPoL: Students' perceptions of learning, SPoT: Students' perceptions of teaching,

SASP: Students' academic self-perceptions, SPoA: Students' perceptions of atmosphere, SSSP: Students' social self-perception

a spirit, a culture; a big buzzing confusion, a complex, chaotic kind of situation, with countless components, myriad dynamics and interactions of inputs and processes, inevitable conflicts, and constantly in a state of flux [60]." In terms of the clinical teaching-learning setting, there were lot untold differences observed, as "differences in the orientation toward teaching and learning, the level of autonomy, variety, and workload, the quality of supervision and social support, type and quality of opportunities for practice of important skills and the availability of educational resources [61]." Afterward, the DREEM is certainly a valuable tool for assessing the educational environment in medical education, and its extensive transnational use discloses the necessity of such inventory [4]. Nevertheless, there has conceivably evidence that the DREEM has an insufficient emphasis on founding and upholding its psychometric properties [4]. This study considered the psychometric properties of the DREEM-M in a sample of Malaysian medical students. In this sample, the overall DREEM-M inventory demonstrated a high-level internal consistency. This finding is exactly similar with another Ghanaian study [62]. CFA of the current study found that the one factor model of DREEM-M (Model A), consisting 50 items were not fit, indicating it was multidimensional - which is similar with the original DREEM inventory [6]. Furthermore CFA, it gives the impression that the proposed five-factor structure was not fit (Model B) as all the goodness-of-fit indices did not signify a model fit. This finding also similar with another study of Malaysia [41,63]. SFL for the proposed five-factor structure of the 50-item DREEM-M (Model A) ranged between 0.05 and 0.79 , suggesting that certain items did not represent the internal construct validity being measured; it is in conflicting with original DREEM inventory [6] but similar with another study Swedish study [41]. Whereas, for the best fit model (i.e., model G), the SFL ranged between 0.49 and 0.81 (Fig. 1), indicating that all items contributed highly to the constructs being measured [64]. The Cronbach's alpha values for the five subscales of the 50-item DREEM-M ranged between 0.78 and 0.85 while for the 19-item DREEM-M ranged between 0.69 and 0.79 . The subscales for both versions showed acceptable to a high-level of internal consistency in measuring the five aspects of students' perception of educational climate. The current study findings are quite like a number studies of the translated version of the DREEM inventory in different countries $[41,42,65,66]$.

\section{CONCLUSION}

The current study findings regarding the Bahasa Melayu version of DREEM inventory 50-item inventory failed to achieve a model fit, but it demonstrated a high of internal consistency. The proposed 19item DREEM-M revealed good model fit as its goodness-of-fit indices achieved an acceptable level, and confirmed a high level of internal inconsistency.

\section{ACKNOWLEDGMENT}

The authors are much grateful to those medical students who participated in this study. Furthermore, authors also humbly express their gratitude toward UniSZA authority for their kind cooperation.

\section{REFERENCES}

1. The Executive Council of the World Federation for Medical Education (WFME). International standards in medical education: Assessment and accreditation of medical schools' - Educational programs. A WFME position paper. Med Educ 1998;32(5):549-58

2. Chandran CR, Ranjan R. Students' perceptions of educational climate in a new dental college using the DREEM tool. Adv Med Educ Pract 2015;6:83-92.

3. Bakhshialiabad H, Bakhshi M, Hassanshahi G. Students' perceptions of the academic learning environment in seven medical sciences courses based on DREEM. Adv Med Educ Pract 2015;6:195-203.

4. Cunningham J, Wright C, Baird M. Managing clinical education through understanding key principles. Radiol Technol 2015;86(3):257-73.

5. Hammond SM, O'Rourke M, Kelly M, Bennett D, O’Flynn S. A psychometric appraisal of the DREEM. BMC Med Educ 2012;12:2.

6. Roff S, Mcaleer S, Harden RM, Al-Qahtani M, Ahmed AU, Deza H, et al. Development and validation of the Dundee ready education environment measure (DREEM). Med Teach 1997;19(4):295-9.

7. Rothman AI, Ayoade F. The development of a learning environment: A questionnaire for use in curriculum evaluation. J Med Educ 1970;45(10):754-9. 
8. Marshall RE. Measuring the medical school learning environment. J Med Educ 1978;53(2):98-104.

9. Feletti GI, Clarke RM. Review of psychometric features of the medical school learning environment survey. Med Educ 1981;15(2):92-6.

10. Moore-west M, Harrington DL, Mennin SP, Kaufman A, Skipper BJ. Distress and attitudes toward the learning environment: Effects of a curriculum innovation. Teach Learn Med 1989;1:151-7.

11. General Medical Council: Tomorrow's Doctors. Recommendations on Undergraduate Medical Education London, General Medical Council; 1993. Available from: http://www.gmc-uk.org/Tomorrow_s Doctors_1214.pdf_48905759.pdf. [Last accessed on 2017 Mar 26].

12. Chan DS. Combining qualitative and quantitative methods in assessing hospital learning environments. Int J Nurs Stud 2001;38(4):447-59.

13. Mulrooney A. Development of an instrument to measure the practice vocational training environment in Ireland. Med Teach 2005;27(4):338-42.

14. Rahman NI, Aziz AA, Zulkifli Z, Haj MA, Mohd Nasir FH, Pergalathan $\mathrm{S}$, et al. Perceptions of students in different phases of medical education of the educational environment: Universiti Sultan Zainal Abidin. Adv Med Educ Pract 2015;6:211-22.

15. Mohsena M, Debsarma S, Haque M. Determining the quality of educational climate in a private medical college in Bangladesh via the Dundee ready education environment measure instrument. J Young Pharm 2016;8(3):266-74

16. Roff S. The Dundee ready educational environment measure (DREEM) - A generic instrument for measuring students' perceptions of undergraduate health professions curricula. Med Teach 2005;27(4):322-5.

17. Mohd Said N, Rogayah J, Hafizah A. A study of learning environments in the kulliyyah (faculty) of nursing, international Islamic university Malaysia. Malays J Med Sci 2009;16(4):15-24.

18. Thomas BS, Abraham RR, Alexander M, Ramnarayan K. Students' perceptions regarding educational environment in an Indian dental school. Med Teach 2009;31(5):e185-6.

19. Till H. Identifying the perceived weaknesses of a new curriculum by means of the Dundee ready education environment measure (DREEM) inventory. Med Teach 2004;26(1):39-45.

20. Soemantri D, Herrera C, Riquelme A. Measuring the educational environment in health professions studies: A systematic review. Med Teach 2010;32(12):947-52

21. Vaughan B, Mulcahy J, McLaughlin P. The dreem, Part 2: Psychometric properties in an osteopathic student population. BMC Med Educ 2014; $14: 100$.

22. Schreiber JB, Nora A, Stage FK, Barlow EA, King J. Reporting structural equation modeling and confirmatory factor analysis results: A review. J Educ Res 2006;99(6):323-38.

23. Said H, Badru BB, Shahid M. Confirmatory factor analysis (CFA) for testing validity and reliability instrument in the study of education. Aust J Basic Appl Sci 2011;5(12):1098-103

24. Hernandez R. A short form of the subjective well-being scale for Filipinos. EME Rev 2010;1:105-15.

25. Cabrera P. Author guidelines for reporting scale development and validation results in the journal of the society for social work and research. J Soc Social Work Res 2010;1(2):99-103.

26. Jung J, Neumann M, Wirtz M, Ernstmann N, Staratschek-Jox A, Wolf J, et al. Validation of the "SmoCess-GP" instrument - A short patient questionnaire for assessing the smoking cessation activities of general practitioners: A cross-sectional study. BMC Fam Pract 2010;11:9.

27. Atkinson TM, Rosenfeld BD, Sit L, Mendoza TR, Fruscione M, Lavene D, et al. Using confirmatory factor analysis to evaluate construct validity of the brief pain inventory (BPI). J Pain Symptom Manage 2011:41(3):558-65.

28. Kalk K, Luik P, Taimalu M, Täht K. Validity and reliability of two instruments to measure reflection: A confirmatory study. Trames 2014;18(2):121-34.

29. Hadie SN, Yusoff MS. Assessing the validity of the cognitive load scale in a problem-based learning setting. J Taibah Univ Med Sci 2016;11(3):194e202.

30. Majeed AA, Darmawan GN, Lynch P. A confirmatory factor analysis of attitudes toward mathematics inventory (ATMI). MathEduc 2013;15(1):121-35.

31. Malaysian Qualifications Agency. Code of Practice for Program Accreditation. $2^{\text {nd }}$ ed. Petaling Jaya, Selangor Darul Ehsan, Malaysia: Malaysian Qualifications Agency; 2008.

32. Malaysian Qualifications Agency. Code of Practice for Institutional Audit. $1^{\text {st }}$ ed. Petaling Jaya, Selangor Darul Ehsan, Malaysia: Malaysian
Qualifications Agency; 2008

33. Ismail S, Salam A, Alattraqchi AG, Annamalai L, Chockalingam A, Elena WP, et al. Evaluation of doctors' performance as facilitators in basic medical science lecture classes in a new Malaysian medical school. Adv Med Educ Pract 2015;6:231-7.

34. Bhagat V, Haque M, Simbak NB, Jaalam K. Study on personality dimension negative emotionality affecting academic achievement among Malaysian medical students studying in Malaysia and overseas. Adv Med Educ Pract 2016;7:341-6.

35. Haque M, Rahman NA, Majumder MA, Haque SZ, Kamal ZM, Islam $\mathrm{Z}$, et al. Internet use and addiction among medical students of Universiti Sultan Zainal Abidin, Malaysia. Psychol Res Behav Manag 2016;9:297-307.

36. Costello AB, Osborne JW. Best practices in exploratory factor analysis: Four recommendations for getting the most from your analysis. Pract Assess Res Eval 2005;10(7):1-9.

37. McAleer S, Roff S. A Practical Guide to Using the Dundee Ready Education Environment Measure (DREEM). AMEE Medical Education Guide No. 23. Scotland: AMEE; 2001. p. 29-33.

38. Roff S, McAleer S. What is educational climate? Med Teach 2001;23(4):333-4

39. Khan JS, Tabasum S, Yousafzai UK, Fatima M. DREEM on: Validation of the Dundee ready education environment measure in Pakistan. J Pak Med Assoc 2011;61(9):885-8.

40. Dimoliatis ID, Vasilaki E, Anastassopoulos P, Ioannidis JP, Roff S. Validation of the Greek translation of the Dundee ready education environment measure (DREEM). Educ Health (Abingdon) 2010;23(1):348

41. Jakobsson U, Danielsen N, Edgren G. Psychometric evaluation of the Dundee ready educational environment measure: Swedish version. Med Teach 2011;33(5):e267-74.

42. Riquelme A, Oporto M, Oporto J, Méndez JI, Viviani P, Salech F, et al. Measuring students' perceptions of the educational climate of the new curriculum at the Pontificia Universidad Católica de Chile: Performance of the Spanish translation of the Dundee ready education environment measure (DREEM). Educ Health (Abingdon) 2009;22(1):112.

43. Yusoff MS. The Dundee ready educational environment measure: A confirmatory factor analysis in a sample of Malaysian medical students. Int J Hum Soc Sci 2012;2(16):313-21.

44. Yusoff MS. Stability of DREEM in a sample of medical students: A prospective study. Educ Res Int 2012;2012:1-5.

45. Haque M, Zulkifli Z, Nasir FH, Majumder MA, Yusoff MS, Mustafa A, et al. Perception of tomorrow's health-care connoisseur and front-runners of their educational environment utilizing DREEM inventory in Bahasa Melayu version, the native language of Malaysia. Aus Med J 2017;10(5):396-412.

46. Yusoff MS, Arifin WN. Educational environment and psychological distress of medical students: The role of a deep learning approach. J Taibah Univ Med Sci 2015;10(4):411-8.

47. Brown TA. Confirmatory Factor Analysis for Applied Sciences. New York: The Guilford Press; 2006.

48. Arbuckle JL. IBM SPSS Amos 19 user's Guide. Chicago, US: IBM; 1995. Available from: http://www.amosdevelopment.com/download/ amos.pdf. [Last accessed on 2017 Mar 15].

49. Kline RB. Principles and Practice of Structural Equation Modeling. $3^{\text {rd }}$ ed. New York: Guilford Publications; 2010.

50. Piaw CY. Statistik Penyelidikan Lanjutan. Malaysia: McGraw Hill; 2009

51. Browne MW, Cudeck R. Alternative ways of assessing model fit. Soc Method Res 1992;21(2):230-58.

52. Jöreskog K, Sörbom D. Scientific Software. $3^{\text {rd }}$ ed. Moorsville: LISREL VI Users Guide; 1984

53. Bentler PM. Comparative fit indexes in structural models. Psychol Bull 1990;107(2):238-46.

54. Bentler PM, Bonett DG. Significance tests and goodness of fit in the analysis of covariance structures. Psychol Bull 1980;88(3):588

55. Bollen KA. A new incremental fit index for general structural equation models. Soc Method Res 1989;17(3):303-16.

56. Marsh HW, Hocevar D. Application of confirmatory factor analysis to the study of self-concept: First-and higher order factor models and their invariance across groups. Psychol Bull 1985;97(3):562.

57. Nunally JC. Psychometric Theory. $2^{\text {nd }}$ ed. New York: McGraw Hill; 1978

58. Streiner LD, Norman GR. Health Measurement Scales: A Practical Guide to Their Development and Use. $4^{\text {th }}$ ed. New York: Oxford University Press; 2008.

59. Yusoff MS, Rahim AF, Yaacob M. The development and validity of the medical student stressor questionnaire (MSSQ). ASEAN J Psychiatr 
2010;11(1):1-12

60. Genn JM. AMEE Medical Education Guide No. 23 (Part 1): Curriculum, environment, climate, quality and change in medical education - A unifying perspective. Med Teach 2001;23(5):337-44.

61. Rotem A, Bloomfield L, Southon G. The clinical learning environment. Isr J Med Sci 1996;32(9):705-10.

62. Mogre V, Amalba A. Psychometric properties of the Dundee ready educational environment measure in a sample of Ghanaian medical students. Educ Health (Abingdon) 2016;29(1):16-24

63. Yusoff MS. Psychometric properties of DREEM in a sample of Malaysian medical students. Med Teach 2012;34(7):595-6.
64. Nunnally JC, Bernstein IH. Psychometric Theory. New York, NY: McGraw-Hill; 1994

65. Ostapczuk MS, Hugger A, de Bruin J, Ritz-Timme S, RotthoffT. DREEM on, dentists! Students' perceptions of the educational environment in a German dental school as measured by the Dundee ready education environment measure. Eur J Dent Educ 2012;16(2):67-77.

66. Rotthoff T, Ostapczuk MS, De Bruin J, Decking U, Schneider M, Ritz-Timme S. Assessing the learning environment of a faculty: Psychometric validation of the German version of the Dundee ready education environment measure with students and teachers. Med Teach 2011;33(11):e624-36. 